Ann. Biol. anim. Bioch. Biophys., 1979, 19 (4 B), 1391-1398.

\title{
The antisteroid action of the pineal gland
}

\author{
par Elena DAMIAN
}

«C. I. Parhon » Institute of Endocrinology, 71279 Bd. Aviatorilor, no 34-36

R 76.134, Bucarest, R. S. Romania.

Summary. This study presents data on the antisteroid action of the pineal gland. The administration of melatonin-free pineal extract to rats significantly decreased serum and testicular testosterone, plasma and adrenal corticosterone and total urinary 17 ketosteroid (17 KS) excretion. It also lowered the urinary $17 \mathrm{KS}$ of both testicular and adrenal origin in rabbits. At the same time, administration of bovine pineal extract decreased serum, biliary, hepatic, testicular and adrenal cholesterol, the main precursor of these steroid hormones. Melatonin, a pineal campound, failed to induce comparable effects. This demonstrated that the effects obtained with the pineal extract were not mediated by melatonin. Conversely, pinealectomy, having a completely opposite effect, caused an increase in these biochemical indices. The pineal extract was also found to decrease rat serum pituitary-luteinizing hormone (LH) and follicle-stimulating hormone (FSH). As compared to the control group, pretreatment with pineal extract significantly reduced the LH and FSH response to gonadotropin-releasing hormone $(\mathrm{GnRH})$. This extract also inhibited the $24 \mathrm{hr}$ postcastration rise of serum and pituitary LH and FSH in mature male rats. Pinealectomy increased serum LH and FSH. The action mechanism is discussed.

\section{Introduction.}

The inhibiting role of the pineal gland on the pituitary-gonadal system and on the pituitary-adrenal system has been much discussed (Damian, 1979 ; Relkin, 1976 ; Wurtman and Moskowitz, $1977 a, b)$. However, the specific role of the pineal substances and their manner of action are not yet clear. The pineal compounds with antigonadotropic activity, for instance, can be divided into two groups, according to their chemical nature : indoles and pineal polypeptides (Damian, 1978a; Reiter and Vaughan, 1977). Although in the last few years there has been increasing evidence of extrapineal sources, melatonin is still considered as a preeminently pineal hormone reproducing many of the effects of pineal extracts or correcting some of the effects induced by pinealectomy (Damian, 1974, 1977b ; Wurtman and Moskowitz, 1977a, b). Along with indole compounds, the pineal polypeptides have been the object of many studies. Of the pineal peptides, arginine vasotocin was found to have an antigonadotropic activity (Pavel et al., 1973). 


\section{Material and methods.}

In the present investigations, a melatonin-free extract (Damian and lanas, 1971) was used, obtained according to the technique of Milcu et al. (1963) and containing $30 \mathrm{mg} / \mathrm{ml}$ of pineal powder. In some experiments, melatonin NBC (Nutritional Biochem.) was used dissolved in ethyl alcohol, then diluted with saline solution to a final concentration of 1 p. $100(\mathrm{v} / \mathrm{v})$.

To ascertain the antigonadotropic action of the pineal gland, the effect of pineal substances and of pinealectomy on testosterone was followed in adult male rats weighing $200 \mathrm{~g}$. Each animal received $2 \mathrm{ml} /$ day of pineal extract or saline solution for $1,3,6$ and 12 days. Other animals were given $1 \mu \mathrm{g} /$ day of melatonin or saline solution. Four hours after the single injection, and after 3, 6 and 12 days of treatment with pineal extract, the animals were killed and testosterone radioimmunoassay (RIA) performed on the serum and the testicular tissue (Milcu et al., 1975).

\section{Results and discussion.}

Administration of pineal gland extract significantly decreased both serum and testicular testosterone. Melatonin failed to induce a comparable effect (fig. 1). Orts (1977) obtained similar results using a partially purified pineal extract.

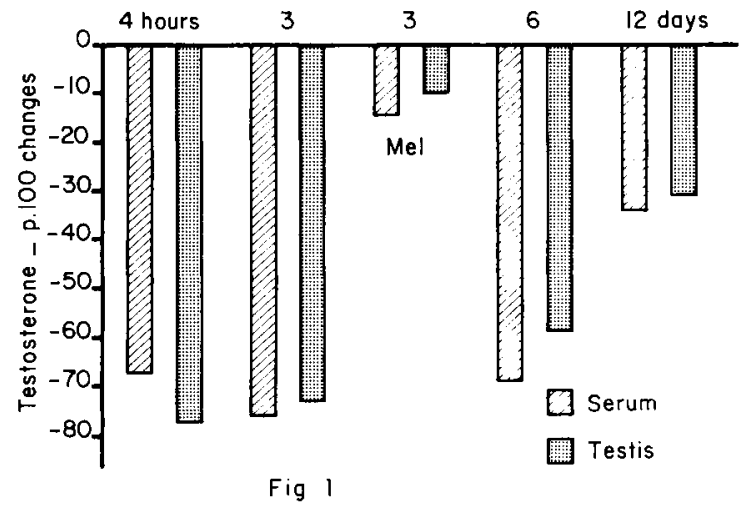

FIG. 1. - Decrease of serum and fesficular testosterone, in rats after pineal extract and melatonin (MEL) administration.

Pinealectomy performed in rats (Damian et al., 1979) induced the opposite effects. i. e. statistically significant increases of serum and testicular testosterone (fig. 2), Kinson and Peat (1971) also obtained an increase of serum testosterone after pinealectomy. These data proved the inhibitory role of the pineal gland on festosterone synhesis.

The effect of pineal extract on corticosterone, the main corticosteroid, was studied in rats in the same way. Corticosterone was fluorimetrically assayed in the plasma and the adrenals (Damian ef al., 1976) 4 hrs after the 1-day injection and after 3,6 and 
12 days of treatment (fig. 3). The pineal extract induced a decrease of plasma corticosterone, especially $4 \mathrm{hrs}$ after the single injection, and a more marked decrease of adrenal corticosterone after 12 days of treatment. Dickson and Hasty (1972) obtained th same decrease in plasma after treatment with pineal extract, while Nir et al. (1971) and Ogle and Kitay (1976) reported an increase of the hormone after pinealectomy in rats. These data proved that the pineal gland interferes in adrenal steroidogenesis, probably through ACTH.

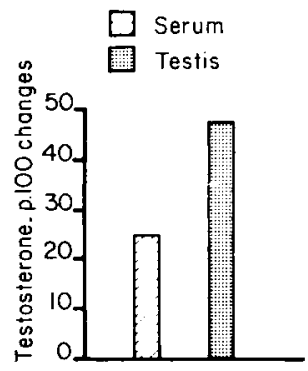

Fig 2

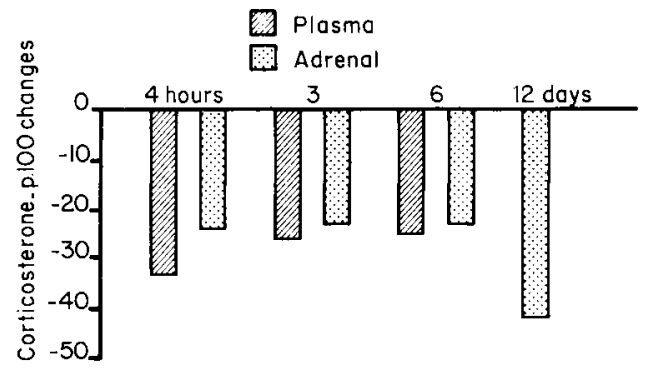

Fig 3

FIG. 2. - Increase of serum and testicular testosterone in rats after pinealectomy.

FIG. 3. - Decrease of plasma and adrenal corticosterone in rats after pineal extract administration.

The study of urinary 17 ketosteroid (17 KS) excretion in rats after administration of pineal extract for 12 days and of melatonin at the abovementioned doses, showed that only the pineal extract significantly reduced the steroid hormones, while pinealectomy on the contrary caused an increase of $17 \mathrm{KS}$ (fig. 4) (Damian, 1977a ; Damian ef al., 1973).

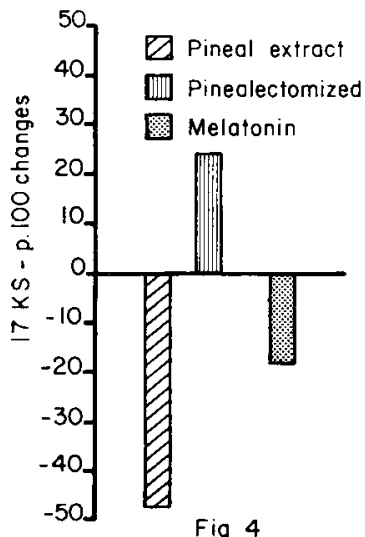

Fig 4

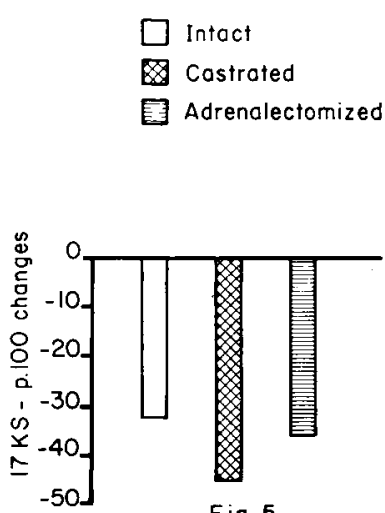

Fig 5

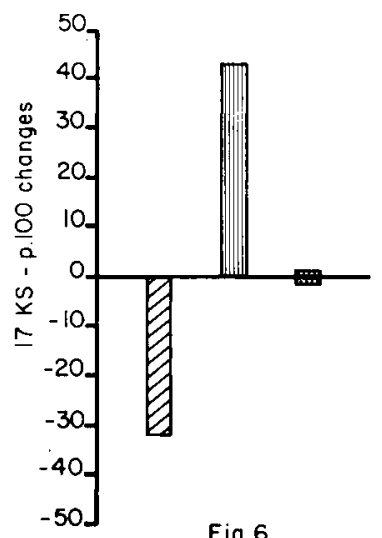

Fig 6

FIG. 4. - Changes of urinary $17 \mathrm{KS}$ in rats after pineal treatment and pinealectomy.

FIG. 5. - Decrease of $17 \mathrm{KS}$ after administration of pineal extract to intact, castrated and adrenalectomized rabbits.

FIG. 6. - Changes of urinary $17 \mathrm{KS}$ in rabbits after pineal treatment and pinealectomy. 
In some previous investigations carried out with I. Milcu the excretion of $17 \mathrm{KS}$ was followed in intact, castrated and adrenalectomized rabbits treated for 10 days with pineal extract $(10 \mathrm{ml} / \mathrm{day})$. The double origine of these hormones was taken into consideration. To determine the effect of pineal extract on adrenal $17 \mathrm{KS}$, the study started 3 weeks after castration by carrying out urinary 17 KS assays 10 days before and 10 days during the treatment. Using the same $17 \mathrm{KS}$ assays, the effect on the testicle was studied in rabbits with bilateral adrenalectomy, maintained with cortisone doses of $2 \mathrm{mg} /$ day. Figure 5 shows that pineal extract significantly decreased both the testicular and the adrenal $17 \mathrm{KS}$. Melatonin administered only to intact rabbits did not change the hormone levels (Damian, 1972). Pinealectomy induced an increase of $17 \mathrm{KS}$. Figure 6 gives the percent of urinary $17 \mathrm{KS}$ changes after treatment with pineal extract and after pinealectomy.

Besides the decrease of $17 \mathrm{KS}$ in rabbits, the pineal extract also induced a decrease of serum cholesterol, while pinealectomy had the opposite effect (Damian, 1972). Hence the question was raised whether the decrease of these hormones could not be partly due to the decrease of serum cholesterol, a necessary intermediary in the biosynthesis of steroid hormones. To solve this problem, Milcu ef al. (1966) followed the effect of pineal extract and of pinealectomy on biliary cholesterol in rabbits. Figure 7 shows the opposite effects obtained by pinealectomy as compared with those noted after treatment with pineal extract. Continuing these investigations in rats, I observed the inhibitory effect of the pineal gland on cholesterol synthesis. Figure 8 shows that treatment with pineal extract induced a decrease of serum, hepatic, adrenal and testicular cholesterol, while after pinealectomy these biochemical levels increased (Damian, 1978b). No such effects were noted after melatonin (Damian et al., 1974). The inhibition of hepatic, adrenal and testicular cholesterol synthesis would at least partly explain

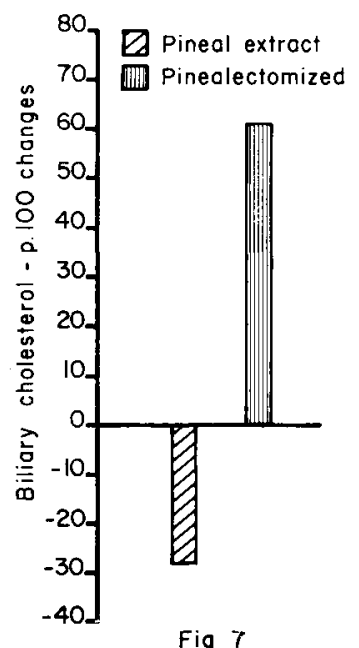

Fig 7

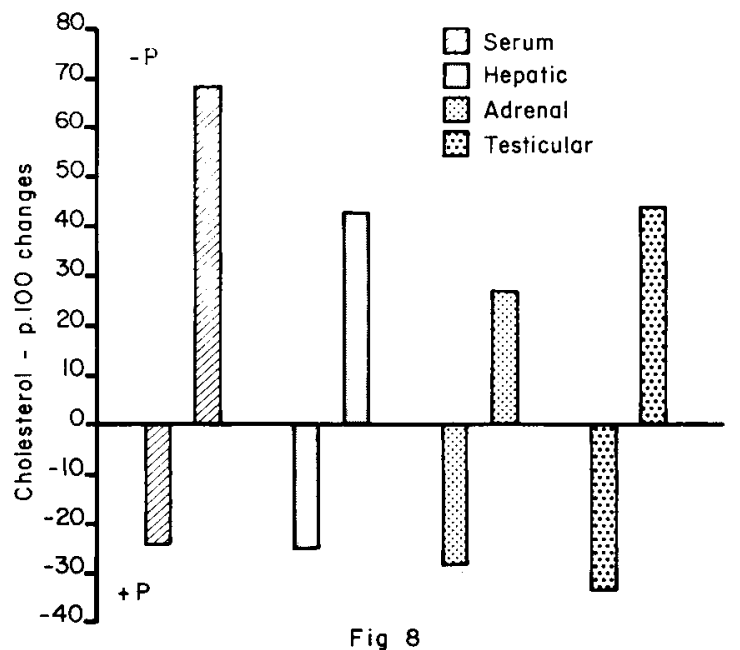

Fig 8

FIG. 7. - Changes of biliary cholesterol in rabbits after pineal extract administration and pinealectomy.

FIG. 8. - Changes of serum, hepatic, adrenal and testicular cholesterol in rats after pineal exfract administration (+ P) and pinealectomy ( $-\mathrm{P})$. 
the decrease of testosterone and corticosterone after treatment with pineal extract. The role of the pineal gland in lipid metabolism has been studied by Damian (1978b). The following facts on the antigonadotropic activity of the pineal gland have come to light recently :

a) administration of pineal extract for 3 days at a dose of $2 \mathrm{ml} /$ day significantly decreases serum LH by 45 p. 100 and serum FSH by 36 p. 100 (Damian et al., 1978a), while administration of $1 \mu \mathrm{g}$ melatonin per day does not show this effect. These findings have confirmed those of Orts (1977);

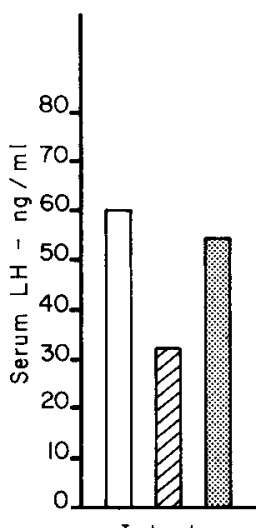

Intact

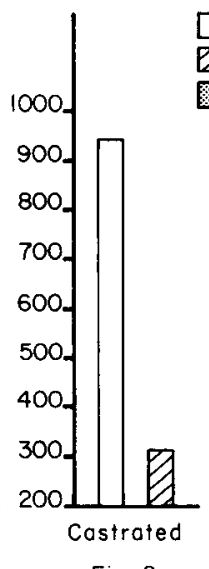

Fig 9
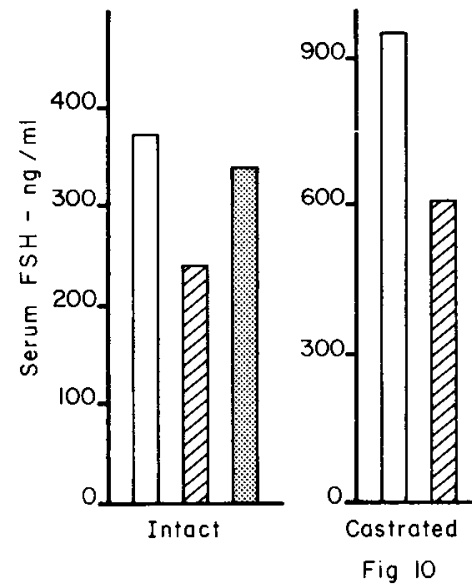

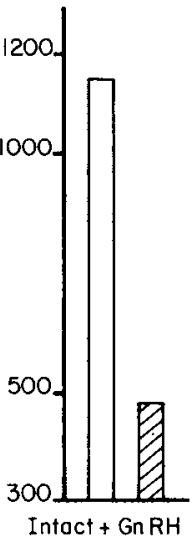

Intoct + Gn RH

FIG. 9. - Decrease of serum LH in intact and castrafed rats as well in normals freafed with $G$ nRH.

FIG. 10. - Decrease of serum FSH in intoct and castrated rats as well in normals treated with GnRH.

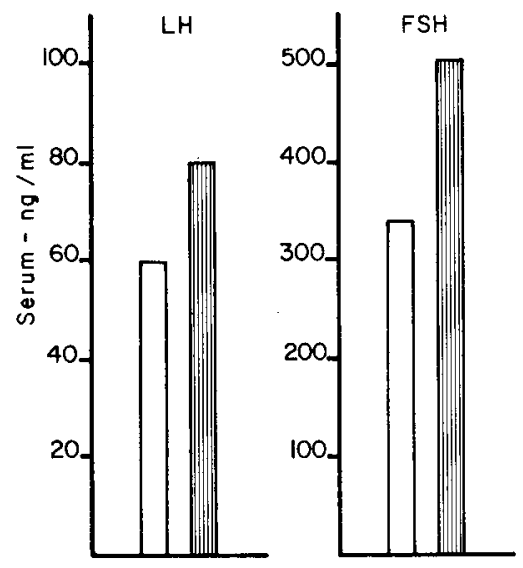

Fig If
IIII. Pinealectomized

Intact
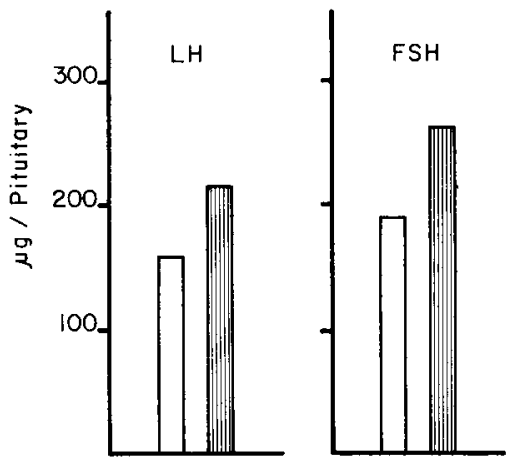

Fig 12

FIG. 11. - Increase of serum LH and FSH in rats affer pinealectomy.

FIG. 12. - Increase of pifuitary LH and FSH in rats after pinealectomy. 
b) administration of pineal extract immediately after castration significantly inhibits serum LH and FSH increment (66 and 36 p. 100, respectively) (Damian ef al., 1978b). These findings also confirm those of Orts ef al. (1974) ;

c) administration of pineal extract inhibits the pituitary response to gonadotropinreleasing hormone $(\mathrm{GnRH})$, i. e. if reduces serum LH by 50 p. 100 and serum FSH by 56 p. 100 . Male rats received $2 \mathrm{ml} /$ day of pineal extract for 2 days. Thirty minutes after the injection on the second day, those animals and a control group received $1 \mu \mathrm{g} / \mathrm{ml}$ of $\mathrm{GnRH}$-Serono in a single injection. The animals were killed $1 \mathrm{hr}$ after the injection with GnRH (Damian ef al., 1978c). The results of the $\mathrm{LH}$ and FSH radioimmunoassays performed are given in figures 9 and 10 ; figures 11 and 12 show the increases of serum and pituitary LH and FSH induced in rats by pinealectomy 2 months after the operation. These findings are in agreement with those of Alonso ef al. (1978).

\section{Conclusions.}

The data show a direct effect of the pineal gland on pituitary synthesis and release of $\mathrm{LH}$ and $\mathrm{FSH}$, but the hypothalamic route cannot be excluded (Kappers ef al., 1974). These data also demonstrate that the mechanism of pineal gland action on the reproductive function is complex : the effects obtained with the pineal extract in this study are not due to melatonin, and a substance isolated in the urine of children and assumed to be of pineal origin has proved to have the same antisteroid and antigonadotropic activity as the pineal extract (Damian, 1976).

All these studies have contributed new data which help to clarify the inhibitory role of the pineal gland on the reproductive function.

4th Workshop on « Development and maturation of the reproductive organs and functions 》 Luynes, France, octobre 1978.

Résumé. L'épiphyse a une action antistéoïdienne. L'injection d'un extrait épiphysaire dépourvu de mélatonine entraîne chez le rat une diminution significative du taux de testostérone sérique et testiculaire, de corticostérone plasmatique, du contenu en corticostérone de la glande surrénale et des 17 cétostéroïdes urinaires. Chez le lapin également, cet extrait épiphysaire a un effet inhibiteur sur le testicule ef la surrénale (abaissement des $17 \mathrm{CS})$.

Le même extrait entraîne une baisse significative du cholestérol sanguin, biliaire, hépatique, testiculaire et surrénalien. On ne constate pas d'effets semblables après administration de mélatonine, le principal indole de la glande pinéale. Inversement l'épiphysectomie provoque l'accroissement des indices biochimiques mentionnés. Chez le rat l'extrait épiphysaire provoque aussi une diminution de la $\mathrm{LH}$ et de la $\mathrm{FSH}$ sériques, tandis que l'épiphysectomie est suivie d'une augmentation de la concentration des hormones gonadotropes. Le prétraitement avec le même extrait inhibe la réponse de LH et FSH à une injection de GnRH par rapport aux témoins. Chez les rats castrés on constate une chute importante de la LH et de la FSH sériques après administration de l'extrait épiphysaire. Le mécanisme d'action antistéroïdienne de l'épiphyse est discuté. 


\section{References}

ALONSO R., PRIETO L., MAS M., 1978. Increase in pituifary levels of luteinizing hormone and follicle-stimulating hormone after pinealectomy in both intact and castrated rats. Endocrinology, 102, $1534-1539$.

DAMIAN E., 1972. Pineal gland action on sexual function and lipid metabolism. St. Cerc. Endocrinol., 23, 389-396.

DAMIAN E., 1974. Melatonin and the endocrine function. Rev, roum. Endocrinol., 11, 81-95.

DAMIAN E., 1976. Human urinary antisteroid substance with pineal-polypeptides-like activity. Rev. roum. Méd. Endocrinol., 14, 3-12.

DAMIAN E., 1977a. The role of the pineal gland in reproduction. Rev. roum. Méd. Endocrinol., 15, 3-11.

DAMIAN E., 1977b. Extrapineal gland sources of melatonin. Rev. roum. Méd. Endocrinol., 15, 65-66.

DAMIAN E., 1978a. Pineal compounds with antigonadotropic activity. Rev. roum. Méd. Endocrinol., 16, 3-11.

DAMIAN E., 1978b. The role of the pineal gland in the lipid metabolism. Rev. roum. Méd. Endocrinol., 16, $179-189$.

DAMIAN E., 1979. The antigonadotropic activity of the pineal gland. Rev. roum. Méd. Endocrinol., 17, 3-11.

DAMIAN E., IANAS O., 1971. The control of melatonin presence in pineal extracts. St. Cerc. Endocrinol. 22, 449-453.

DAMIAN E., IANAS O., BADESCU 1., 1973. The action of melatonin on cholesterol and 17 ketosteroids to rats. St. Cerc. Endocrinol., 24, 105-108.

DAMIAN E., IANAS O., BADESCU I., 1974. Contrôle de l'action de la mélatonine sur les lipides tissulaires. Rev. roum. Méd., 12, 32-34.

DAMIAN E., IANAS O., BADESCU I., 1976. Decrease of plasma and adrenal corticosterone after pineal polypeptides administration to rats. Rev. roum. Méd. Endocrinol., 14, 27-30.

DAMIAN E., IANAS O., BADESCU I., 1979. Effect of pinealectomy on testicular testosterone, cholesterol and ascorbic acid in rats. Rev. roum. Méd. Endocrinol., 17, 33-37.

DAMIAN E., IANAS O., BADESCU I., OPRESCU M., 1978a. Anti LH and FSH activity of melatoninfree pineal extract. Neuroendocrinology, 26, 325-332.

DAMIAN E., IANAS O., BADESCU I., OPRESCU M., 1978b. Inhibitory action of pineal extract on LH ond FSH. Rev. roum. Méd. Endocrinol., 16, 257-262.

DAMIAN E., IANAS O., BADESCU I., OPRESCU M., 1978c. Inhibition of pituitary response to gonadotropin releasing hormone $(\mathrm{GnRH})$ by melatonin free pineal extract (in press).

DICKSON K. L., HASTY D. L., 1972. Effects of the pineal gland in unilaterally adrenalectomized rats. Acta endocr. Copenh, 70, 438-444.

KAPPERS J. A., SMITH A. R., DE VRIES R. A. C., 1974. The mammalian pineal gland and its control of hypothalamic activity. Progr. Brain. Res., 41, 149-174.

KINSON G. A., PEAT F., 1971. The influence of illumination, melatonin and pinealectomy on testicular function in the rat. Life Sci, 10, 259-269.

MILCU I., DAMIAN E., IONESCO M., POPESCO I., 1966. L'action de l'épiphyse sur la synthèse du cholestérol hépatique. Rev. roum. Endocrin., 3, 35-39.

MILCU S. M., DAMIAN E., IANAS O., BADESCU I., OPRESCU M., 1975. Decrease in serum and testicular testosterone after administration of pineal polypeptides to rats. Endocr. exp., 9, 259269.

MILCU S. M., MILCU I., NANU L., 1963. Le rôle de la glande pinéale dans le métabolisme des glucides. Ann. Endocr., 24, 233-254.

NIR I., SCHMIDT U., HIRSCHMANN N., SULMAN F. G., 1971. The effect of pinealectomy on rat plasma corticosterone levels under various condition of light. Life Sci., 10, 317-324.

OGLE T. F., KITAY J. I., 1976. Effects of pinealectomy on adrenal function in vivo and in vitro in female rats. Endocrinology, 98, 20-24.

ORTS R. J., 1977. Reduction of serum LH and testosterone in male rats by a partially purified bovine pineal extract. Biol. Reprod., 16, 249-254. 
ORTS R. J., BENSON B., COOK B. F., 1974. LH inhibitory properties of aqueous extracts of ra pineal gland. Life Sci., 14, 1501-1510.

PAVEL S., PETRESCU M., VICOLEANU N., 1973. Evidence of central gonadotropin inhibiting activity of arginine vasolocin in the female mouse. Neuroendocrinology, 11, 370-374.

REITER R. J., VAUGHAN M. K., 1977. Pineal antigonadotropic substance polypeptides and indoles. Life Sci, 21, 159-172.

RELKIN R., 1976. The pineal. Eden Press, Montreal.

WURTMAN R. J., MOSKOWITZ M. A., 1977a. The pineal organ (First of two parts). N. Engl. J. Med., 296, 1329-1333.

WURTMAN R. J., MOSKOWITZ M. A., 1977b. The pineal organ (Second of two parts). N. Engl. J. Med., 296, 1383-1386. 